NASA/TM-2002-211970

\title{
Solar Electric Propulsion Vehicle Design Study for Cargo Transfer to Earth-Moon L1
}

Timothy R. Sarver-Verhey, Thomas W. Kerslake, Vincent K. Rawlin, Robert D. Falck, Leonard J. Dudzinski, and Steven R. Oleson

Glenn Research Center, Cleveland, Ohio 
Since its founding, NASA has been dedicated to the advancement of aeronautics and space science. The NASA Scientific and Technical Information (STI) Program Office plays a key part in helping NASA maintain this important role.

The NASA STI Program Office is operated by Langley Research Center, the Lead Center for NASA's scientific and technical information. The NASA STI Program Office provides access to the NASA STI Database, the largest collection of aeronautical and space science STI in the world. The Program Office is also NASA's institutional mechanism for disseminating the results of its research and development activities. These results are published by NASA in the NASA STI Report Series, which includes the following report types:

- $\quad$ TECHNICAL PUBLICATION. Reports of completed research or a major significant phase of research that present the results of NASA programs and include extensive data or theoretical analysis. Includes compilations of significant scientific and technical data and information deemed to be of continuing reference value. NASA's counterpart of peerreviewed formal professional papers but has less stringent limitations on manuscript length and extent of graphic presentations.

- TECHNICAL MEMORANDUM. Scientific and technical findings that are preliminary or of specialized interest, e.g., quick release reports, working papers, and bibliographies that contain minimal annotation. Does not contain extensive analysis.

- CONTRACTOR REPORT. Scientific and technical findings by NASA-sponsored contractors and grantees.
- CONFERENCE PUBLICATION. Collected papers from scientific and technical conferences, symposia, seminars, or other meetings sponsored or cosponsored by NASA.

- SPECIAL PUBLICATION. Scientific, technical, or historical information from NASA programs, projects, and missions, often concerned with subjects having substantial public interest.

- TECHNICAL TRANSLATION. Englishlanguage translations of foreign scientific and technical material pertinent to NASA's mission.

Specialized services that complement the STI Program Office's diverse offerings include creating custom thesauri, building customized databases, organizing and publishing research results ... even providing videos.

For more information about the NASA STI Program Office, see the following:

- Access the NASA STI Program Home Page at http://www.sti.nasa.gov

- E-mail your question via the Internet to help@sti.nasa.gov

- Fax your question to the NASA Access Help Desk at 301-621-0134

- Telephone the NASA Access Help Desk at 301-621-0390

- Write to:

NASA Access Help Desk

NASA Center for AeroSpace Information 7121 Standard Drive

Hanover, MD 21076 
NASA/TM-2002-211970

\section{Solar Electric Propulsion Vehicle Design Study for Cargo Transfer to Earth-Moon L1}

Timothy R. Sarver-Verhey, Thomas W. Kerslake, Vincent K. Rawlin, Robert D. Falck, Leonard J. Dudzinski, and Steven R. Oleson

Glenn Research Center, Cleveland, Ohio

Prepared for the

38th Joint Propulsion Conference and Exhibit

cosponsored by the AIAA, ASME, SAE, and ASEE

Indianapolis, Indiana, July 7-10, 2002

National Aeronautics and

Space Administration

Glenn Research Center 


\section{Acknowledgments}

The development of the SEP transfer vehicle system model was a joint effort by the Power and Propulsion Office, the Power and On-board Propulsion Technology Division, and the Systems Engineering Division, through the Systems Assessment Team. The authors would like to acknowledge the assistance of these organizations in the

system modeling. Also, the authors acknowledge the service of NASA LaRC personnel on the RASC program who are responsible for creation of the graphics of the SEP vehicle shown in this report, as well as many others.

This report contains preliminary

findings, subject to revision as analysis proceeds.

Available from

NASA Center for Aerospace Information 7121 Standard Drive

Hanover, MD 21076
National Technical Information Service 5285 Port Royal Road Springfield, VA 22100 


\title{
SOLAR ELECTRIC PROPULSION VEHICLE DESIGN STUDY FOR CARGO TRANSFER TO EARTH-MOON L1
}

\author{
Timothy R. Sarver-Verhey, ${ }^{*}$ Thomas W. Kerslake, Vincent K. Rawlin, ${ }^{\ddagger}$ \\ Robert Falck, ${ }^{\dagger}$ Leonard J. Dudzinski, ${ }^{*}$ and Steven R. Oleson ${ }^{*}$ \\ National Aeronautics and Space Administration \\ Glenn Research Center \\ Cleveland, Ohio 44135
}

\begin{abstract}
A design study for a cargo transfer vehicle using solar electric propulsion was performed for NASA's Revolutionary Aerospace Systems Concepts program. Targeted for 2016, the solar electric propulsion (SEP) transfer vehicle is required to deliver a propellant supply module with a mass of approximately 36 metric tons from Low Earth Orbit to the first Earth-Moon libration point (LL1) within 270 days. Following an examination of propulsion and power technology options, a SEP transfer vehicle design was selected that incorporated largearea $\left(\sim 2700 \mathrm{~m}^{2}\right)$ thin film solar arrays and a clustered engine configuration of eight $50 \mathrm{~kW}$ gridded ion thrusters mounted on an articulated boom. Refinement of the SEP vehicle design was performed iteratively to properly estimate the required xenon propellant load for the out-bound orbit transfer. The SEP vehicle performance, including the xenon propellant estimation, was verified via the SNAP trajectory code. Further efforts are underway to extend this system model to other orbit transfer missions.
\end{abstract}

\section{INTRODUCTION}

In 2001, one element of the Revolutionary Aerospace Systems Concepts (RASC) program was to develop space related concepts in an Orbital Aggregation and Space Infrastructure Systems (OASIS) framework. ${ }^{1}$ OASIS is a set of concepts that provide common infrastructure for enabling a large class of space missions. The concepts include communication, navigation and power systems, propellant modules, tank farms, habitats, and transfer systems using several propulsion technologies. OASIS features the in-space aggregation of systems and resources to support the mission objectives.

A reusable Hybrid Propellant Module (HPM) that combines both chemical and electric propulsion (EP) propellant in conjunction with modular orbital transfer/ engine stages has been targeted as the first OASIS concept. The HPM would provide chemical propellant for crew transfers and EP propellant for slower HPM delivery and return. The HPM will be driven by a set of mission and concept requirements that encompass the "sweet spot" for given set of Exploration Design
Reference Missions and future Low Earth Orbit (LEO) commercialization scenarios. The concept will feature a high level of reusability and will be supported by inexpensive launch of propellant and logistics payloads from the Earth. The anticipated benefits of modular transfer vehicles and propellant supplies are reduced future mission costs and increased mission robustness and flexibility for future space exploration and commercialization initiatives.

The initial HPM "baseline" resulted from a focused Sun - Earth L2 mission concept evaluated in fall of $2000{ }^{1}$ The Earth-Moon L1 (located between the Earth and Moon at a distance of approximately 320,000 $325,000 \mathrm{~km}$ from the Earth and referred to as LL1) mission for the HPM begins with the assumption that humans will return to the Lunar surface for scientific operations and that a Gateway station at LL1 facilitates this return and also provides a facility for science missions and missions beyond the moon. In order to provide this capability, HPMs are used along with propulsion and crew transfer vehicles to ferry a crew out to and return from the gateway. A SEP transfer vehicle was selected for the cargo phases, which

\footnotetext{
* Technical Staff, Member AIAA

† Senior Member AIAA

$\dagger$ Student Member AIAA
} 
included delivery of loaded HPMs and other non-time critical (i.e., not crewed) elements, as well as return of empty HPMs to LEO. After delivery of the HPM module, the SEP transfer vehicle is placed in a safe parking orbit until it is needed.

During the preliminary phase of the HPM program, a SEP transfer vehicle was selected to deliver the HPM to LL1 because it is a non-time critical cargo. The HPM vehicle consists primarily of cryogenically stored hydrogen and oxygen propellants required to supply the rocket engines on the crew transfer vehicle for a return trip to LEO. It was also decided that the xenon propellant for the EP system would be cryogenically stored within the HPM. Xenon gas is supplied to the thrusters on the SEP transfer vehicle during operation via a fluids interface that serves as the main attachment point between the two vehicle elements. The remainder of the HPM mass, approximately $11 \%$, is support structure and operating systems. A summary of the mission requirements for the SEP transfer vehicle is provided in Table 1 . These requirements were developed by the HPM program leads at NASA Langley Research Center.

Table 1. RASC Hybrid Propellant Module cargo mission specifications

\begin{tabular}{|c|c|}
\hline Requirement & Value \\
\hline Delivered payload (not SEP, & 36.3 \\
xenon), metric tons & \\
\hline Initial Altitude/ Inclination, & $400 \mathrm{~km} /$ \\
$\mathrm{km} / \mathrm{deg}$. & $51.6^{\circ}$ \\
\hline Final Altitude/ Inclination, & $320,000 /$ \\
km/deg. (Earth-Moon L1) & $19.5^{\circ}$ \\
\hline Outbound Trip Time Limit, days & $<270$ \\
\hline Mission Timeframe & 2016 \\
\hline
\end{tabular}

\section{STUDY OBJECTIVE}

NASA Glenn Research Center (GRC) was tasked with supporting the SEP transfer vehicle development. This effort evolved into the team at GRC developing a complete spacecraft system model for the SEP transfer vehicle with sufficient versatility to be readily applied to other high-power orbit transfer missions. This system model was the result of the investigation into the requirements of the power and propulsion subsystems that would support the HPM cargo mission. The goals of this investigation were threefold: first, determine the mass of the SEP transfer vehicle with the HPM that is able to deliver the required HPM fuel load within the proscribed trip time; second, determine propulsion and power generation characteristics that enable successful completion of this mission; and third, determine the characteristics of the remaining subsystems of the SEP transfer vehicle so that a vehicle mass could be determined to a relatively high degree of fidelity. The SEP vehicle system model was also desired to execute trade studies for different power and propulsion technology options. This report will describe the spacecraft configuration developed for the system model, technology options examined for primary subsystems, and the methodology employed to determine orbit transfer performance. It concludes with discussion of other applications of this system model and on-going activities in 2002.

\section{SPACECRAFT DESIGN}

Early in the examination of the SEP vehicle performance it became apparent that the elements of the vehicle needed to be distributed on a relatively large structure so that the propulsion system did not destructively interfere with the solar arrays. Employing a boom arm similar to a previous system developed at NASA GRC for a Mars mission, ${ }^{2}$ the propulsion subsystem was mounted at one end of the boom while the solar arrays were mounted on the main vehicle structure to which the other end of the boom is attached. This separation insures that the solar arrays are protected from effluent from the thrusters.

\section{Subsystem Technology Selection}

Options for the primary technologies used in the SEP transfer vehicle were investigated to determine the best fit for the HPM delivery mission. These technologies will be discussed in the following sections. At the request of the NASA LaRC program leads, near-term and 15-year projections for the various technologies employed were developed. The far-term technology projections developed by the relevant technologists at NASA GRC and used in this design study are summarized in Table 2 (located at the end of this report).

Propulsion Of the three propulsion technologies listed in Table 2, Gridded Ion and Hall Effect thrusters provided the best performance for a low thrust spiral trajectory out to LL1. Gridded ion thrusters were selected because they were found to have a total lower propellant requirement for this mission and have a substantially longer lifetime than the Hall thrusters, which reduced hardware replacement costs. While these 'benefits' were achieved at the expense of longer trip times, the ion thrusters were able to meet the mission requirements. The specifications for the thruster incorporated into the system model are compiled in Table 3. The number and configuration of the ion thrusters are discussed in the next section. 
Table 3. Gridded Ion Thruster Specifications

\begin{tabular}{|c|c|}
\hline Characteristic & Value \\
\hline Operating Power, $\mathrm{kW}$ & 49.5 \\
\hline Thruster Efficiency, \% & 70.0 \\
\hline Specific Impulse, sec. & 3300 \\
\hline Thruster Size, cm dia. & 60.0 \\
\hline Thruster Lifetime, hours & 15,000 \\
\hline Specific Mass, $\mathrm{kg} / \mathrm{kW}$ & 1.25 \\
\hline $\begin{array}{c}\text { PPU/Thermal Control system } \\
\text { Specific Mass, } \mathrm{kg} / \mathrm{kW}\end{array}$ & 4.40 \\
\hline PPU Efficiency, \% & 94.0 \\
\hline
\end{tabular}

Power Generation For solar power generation, thin film and multi-band gap photovoltaic cells were investigated as the most qualified options. Since it was estimated that approximately $450 \mathrm{kWe}$ would need to be delivered to the thrusters, it was expected that any array meeting these requirements would be quite large.

Hence, size and weight were important drivers in the technology selection. Preliminary results showed that thin-film based arrays, while significantly larger than the multi-band gap (MBG) arrays, were also typically lighter than those arrays. The mass benefit of the thinfilm arrays increased further when an advanced array support architecture was used. This support architecture, which is under development by AEC-Able, is referred to as the 'SquareRigger." Consequently, thinfilm arrays were selected for the SEP transfer vehicle; the parameters of the arrays are listed in Table 4. In addition to having a light-weight structure, the arrays are also operated at $500 \mathrm{~V}$ nominally. While operation at this high voltage is aggressive, it is necessary to keep the mass of the power cabling at an acceptable level. While radiation degradation effects were neglected for this mission, it is expected that arrays will be designed to limit the impact. Additionally, the usable lifetime of the arrays was limited to two years, or two trips between LEO and LL1. Energy storage capability was minimal on the SEP vehicle because thrusting was not performed during shadow periods and therefore engine power did not have to be supplied at these times.

Table 4. Photovoltaic Array Specifications

\begin{tabular}{|c|c|}
\hline Characteristic & Value \\
\hline Cell Type & $\begin{array}{c}\mathrm{Cu}(\mathrm{In}, \mathrm{Ga}) \\
\left(\mathrm{Se}_{2} \text { or } \mathrm{S}_{2}\right)\end{array}$ \\
\hline Cell Efficiency & $19 \%$ \\
\hline Support Architecture & Square Rigger \\
\hline Array Areal Density, $\mathrm{kg} / \mathrm{m}^{2}$ & 0.33 \\
\hline Array Specific Power, W/kg & 390 \\
\hline $\begin{array}{c}\text { Total Specific Power, W/kg } \\
\text { (PMAD, thermal included) }\end{array}$ & 315 \\
\hline
\end{tabular}

Power Processing For the purposes of this study, a generic architecture for the power management and distribution system for the photovoltaic arrays was used with the following critical parameters. The system efficiency was $95 \%$ and the specific power was 3,000 $\mathrm{W} / \mathrm{kg}$. These values were provided for the technology projections compiled in Table 2. The power processor system for the gridded ion thrusters had slightly different values because it was developed in conjunction with the engine rather than a general power management architecture. For the thrusters used in the study, the efficiency of the power processor was $94 \%$ and the specific mass was $4.0 \mathrm{~kg} / \mathrm{kW}$.

Thermal Processing Like power processing, a generic architecture was employed for the thermal control system used to handle heat rejection from the solar arrays power processing system. With an areal density of $11 \mathrm{~kg} / \mathrm{m}^{2}$ and standard assumptions about surface characteristics, the thermal control system mass was estimated by simple radiative heat transfer to a background environment assumed to be at $50{ }^{\circ} \mathrm{C}$. The sizes of the radiators were subsequently determined. The radiators on the base pallet were two rectangular wings with dimensions of $2.5 \mathrm{~m}$ wide by $7.0 \mathrm{~m}$ long. As noted in the previous section, the thermal processing system, sized for the thruster system power processing units, was developed with the thruster system and is projected to have a specific mass of $0.4 \mathrm{~kg} / \mathrm{kW}$. The radiators on the thruster pallet were also comprised of two wings with the dimensions of $2.5 \mathrm{~m}$ wide by $6 \mathrm{~m}$ long.

Several other subsystems were included in the SEP transfer vehicle. However, since they are interest only as mass contributions, they will not be discussed further in this report. The masses for each of these subsystems are shown in Table 5.

Table 5. Miscellaneous Spacecraft Elements

\begin{tabular}{|c|c|}
\hline Component & Mass, kg \\
\hline Thruster Pallet Structure & 75 \\
\hline Base Pallet Structure & 175 \\
\hline $\begin{array}{c}\text { Micrometeriod \& Orbital Debris } \\
\text { Protection }\end{array}$ & 260 \\
\hline $\begin{array}{c}\text { Maneuvering Propellant (Xe) + } \\
\text { tank }\end{array}$ & 2150 \\
\hline HPM Interface & 235 \\
\hline $\begin{array}{c}\text { Attitude Control System (Mom. } \\
\text { Bias wheels, Docking system) }\end{array}$ & 400 \\
\hline Auxiliary Batteries & 25 \\
\hline Guidance, Nav., \& Control system & 30 \\
\hline Control, Data, \& Handling system & 150 \\
\hline
\end{tabular}




\section{Vehicle Configuration}

The SEP transfer vehicle consists of three elements, as illustrated in Figure 1. The first is a flat, disc-shaped metallic pallet upon which nine high power electric thrusters are mounted along with associated power processing and thermal control systems. This thruster pallet is attached to the second element, a semicollapsible articulated boom.

Figure 1. SEP Transfer Vehicle shown without PV arrays and HPM.

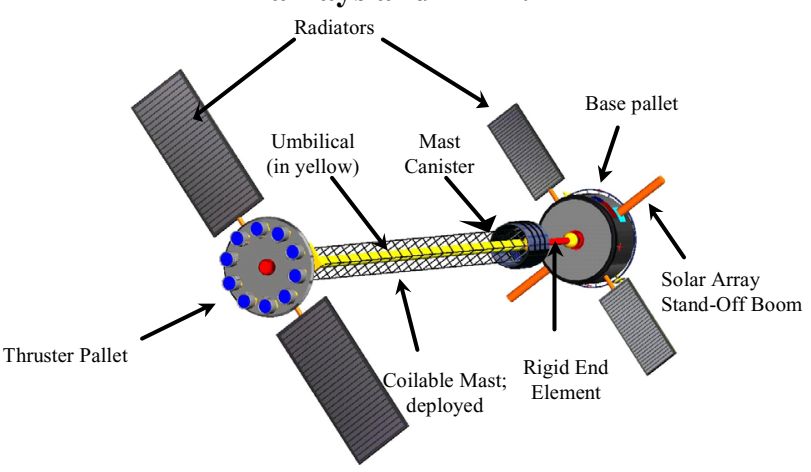

The boom consists of two rigid end elements and a coilable mast, which allows the thrusters to be repositioned to maintain a constant thrusting vector while the remainder of the spacecraft, including the solar arrays, is flown in a solar inertial attitude to maximize power generation. Additionally, the boom enables the thruster pallet to be positioned so that the thruster exhaust plume does not impinge upon and subsequently degrade the solar arrays. To obtain a plausible estimate for mass contributions, two pieces of existing spacecraft hardware were used to size the boom arm elements. For the rigid end booms, the characteristics of the Shuttle Remote Manipulator System (SRMS) ${ }^{4}$ and the International Space Station Remote Manipulator System $(\mathrm{SSRMS})^{5}$ were used to estimate the masses for each segment. The length and mass of the rigid segments are listed in Table 6. For the middle segment, a collapsible structure was required for vehicle launch packaging. Using the coilable mast design developed by AEC-Able for the Shuttle Radar Topography Mission, ${ }^{6}$ a coilable boom was sized by scaling the length to the SEP transfer vehicle requirements. The length and mass of the boom, along with the storage canister mass, are listed in Table 6. Also listed in Table 6 are mass contributions for two-axis wrist joints that were used to join the three segments of the boom together as well as attach the boom at each end. Simple mass contributions were assumed because no development work for appropriately sized wrist joints has yet been undertaken. The final elements of the articulated boom are materials required for operation of the thruster pallet. Electrical power, propellant, and command/control lines are required to be run out to the thruster pallet from the base pallet. Because of the high power delivered to the thruster, the power cabling was comprised of 12 pairs of 0 gauge copper wire. There were two propellant feed lines run out to the end pallet, with one for redundancy. The command/control lines were assumed to be collected into a generic ribbon cable with the necessary redundancy. All of these lines were bundled together within a flexible sheath that served as protection against micrometer damage. This 'umbilical' was routed through the core of the boom elements. The mass contributions of the elements of the umbilical are included in Table 6 .

Table 6. Boom Arm Specifications

\begin{tabular}{|c|c|}
\hline Specification & Value \\
\hline $\begin{array}{c}\text { Rigid Boom Segment Length } \\
\text { (thruster side), m }\end{array}$ & 3.0 \\
\hline $\begin{array}{c}\text { Rigid Boom Segment Mass } \\
\text { (thruster side), kg }\end{array}$ & 31.5 \\
\hline $\begin{array}{c}\text { Rigid Boom Segment Length } \\
\text { (base side), m }\end{array}$ & 4.0 \\
\hline $\begin{array}{c}\text { Rigid Boom Segment Mass } \\
\text { (base side), kg }\end{array}$ & 42 \\
\hline Coilable Mast Length, m & 20 \\
\hline Coilable Mast Mass. kg & 96 \\
\hline Coilable Mast Canister Mass, kg & 505 \\
\hline Wrist Joint Mass, kg & 576 \\
\hline Electrical Cabling Mass, kg & 80 \\
\hline Propellant Line Mass, kg \\
\hline $\begin{array}{c}\text { Command/Control Line Mass, } \\
\text { kg }\end{array}$ & 20 \\
\hline $\begin{array}{c}\text { Protective Cover Mass for elec- } \\
\text { trical, propellant, and command } \\
\text { lines, kg }\end{array}$ & 20 \\
\hline
\end{tabular}

The design of the boom arm will be refined as part of the 2002 activities, which is discussed later in this report.

The third element of the SEP transfer vehicle is a base container to which the solar arrays are mounted and which contains associated power processing and thermal control systems, along with command and control, guidance and navigation, and attitude control systems. In addition, a supply of xenon propellant for pre-HPM maneuvering is located in the base structure. Finally, the propellant interface and mating fixture for attachment to the HPM are located on this pallet. The mass contributions from each of these systems are compiled in Table 5. 


\section{ORBIT TRANSFER PERFORMANCE}

Orbit transfer vehicles operating between LEO and higher orbits, particularly GEO, under low-thrust continuous propulsion have been studied extensively in the past. $^{7,8,9}$ Traditionally, the spacecraft is spiraled out from the starting orbit to its destination. This approach minimizes the propellant required for the transfer, at the cost of increased transfer time. Additionally, the slowly-changing nature of the spiral transfer enables the orbit-averaging technique to accurately assess the trajectory for transfer. ${ }^{10}$

Vehicle configuration can contribute to the orbit transfer capability if it imposes limits on power generation or thrusting. In order to maximize power generation, the SEP transfer vehicle with the HPM maintains a solar inertial attitude with the solar array plane perpendicular to the Sun vector throughout the orbit transfer. When the thrusters are operating, the articulated boom points the resultant thrust vector as close as possible through the vehicle center of mass. This has the twofold benefit of maintaining the vehicle's attitude and maximizing the net thrust. Additionally, the thrust can be maintained and varied optimally while any periodic attitude changes in the SEP/HPM vehicle (i.e. array pointing) can be minimized.

Preliminary Assessment An iterative process for vehicle development was taken because of the following considerations:

1. Evolving vehicle definition

2. Increasing fidelity of vehicle subsystems designs during the course of this study

The orbit transfer performance via a continuous, lowthrust spiral (tangential thrusting primarily with inclination change distributed over the transfer) was investigated using a relatively simple orbit averaging technique derived from Stuhlinger's optimal specific impulse algorithm. ${ }^{11}$ Using the systems parameters described in Tables 2 through 6 , the technique determines transfer characteristics based on initial masses, locations, and propulsion and power characteristics. Because the starting and final locations and trip time were fixed, the initial mass was the primary input and the propellant mass, propulsion performance and power requirements were the primary outputs for the iterated analysis. After each iteration, the initial vehicle mass in LEO was adjusted, which changed the propellant load. With increasing vehicle mass, the propulsion system was adjusted by changing the number of thrusters. This then resulted in revising the solar arrays, power processing, and cabling characteristics to support the required power demand, as well as changed the required propellant load. Once the vehicle configuration was updated to reflect these changes, the transfer performance was tested again. The analysis was repeated until the target payload mass was delivered to LL1 within the required time period. After convergence to the target payload was achieved, the vehicle performance and final mass breakdown was then verified with the high fidelity orbit trajectory code.

High Fidelity Assessment In the high fidelity analysis, the orbit transfer was executed in several phases. The first phase is a geocentric spiral where the thrust vector direction is defined by the weighted blend of three steering laws: tangential steering, eccentricity change steering, and inclination change steering. Each steering law defines the varying thrust direction throughout each orbit passage that, for a given amount of thrust, provides a maximum change in semi-major axis, eccentricity, and inclination, respectively. The unit thrust vectors instantaneously defined by each law are weighted and combined to obtain the appropriate thrust vector direction at a given point in the orbit. The instantaneous weight of each steering law is optimized so that the transfer is accomplished for a minimal propellant mass. Transit time is also minimized at the expense of increased power level. The thruster output always defines the thrust vector magnitude, which is maximized except when the Sun's illumination of the transfer vehicle is blocked by the Earth. During these shadow periods the thruster are turned off. Typically, the dominance of one law over the others changes during the transit. Tangential steering dominates the trajectory from LEO out to a semi-major axis of approximately $13,000 \mathrm{~km}$ to minimize the time spent in the radiation belts, after which eccentricity change steering is phased in with increasing weight as orbit eccentricity increases. Once the orbit becomes eccentric, thrusting to change inclination is efficient near apogee. Here inclination change steering is blended each orbit when the spacecraft true anomaly is such that maximum eccentricity steering is inefficient. The final phase of the transfer occurs after the SEP/HPM vehicle orbit reaches an apogee of about $300,000 \mathrm{~km}$ to $325,000 \mathrm{~km}$ where, when apogee passage is phased with the Moon, the Moons gravity pulls the spacecraft into LL1. When this happens. the SEP/HPM vehicle inserts into a halo orbit about LL1. Again, thrust vector steering is defined to accomplish this optimally, for a minimal propellant mass.

The SEP transfer vehicle performs the inbound transit from LL1 to LEO in the same way as the outbound transit, albeit with the thrust phases in reverse. The SEP/HPM vehicle thrusts to move the spacecraft out 
of LL1 halo orbit and the spacecraft then falls into a geocentric orbit. Again, the thrust vector follows an optimized blend of tangential steering, eccentricity change steering, and inclination change steering laws to move the spacecraft down to circular low Earth orbit at $400 \mathrm{~km}$ at $51.6^{\circ}$ inclination. These results were used to further revise the system model for the final vehicle configuration.

Typically in this approach, the orbit averaging technique tended to over-estimate the propellant load by approximately $5 \%$. However, the initial mass in LEO was over-estimated and the trip time was underestimated by less than $1 \%$. The relatively small variances for these parameters support the validity of this approach.

\section{SEP TRANSFER VEHICLE DESIGN RESULTS}

The final vehicle configuration that met the RASC requirements was determined to have an IMLEO of $59,800 \mathrm{~kg}$. Of this mass, the SEP transfer vehicle dry mass was 11.3 metric tons (with $20 \%$ contingency). The spacecraft propulsion system consisted of eight gridded ion thrusters that produced a net thruster of $20 \mathrm{~N}$. The solar arrays needed to generate $448 \mathrm{kWe}$ to support these engines as well as provide $5 \mathrm{~kW}$ for on-board systems operation. These arrays consisted of two wings with a total area of $2,685 \mathrm{~m}^{2}$. The xenon propellant load for the outbound orbit transfer was found to be 12.2 metric tons. A mass breakdown of the major elements is shown in Figure 2. Additionally, the SEP transfer vehicle is shown graphically in Figure 3. This vehicle performance satisfied the HPM program requirements and was incorporated into the 2001 HPM mission report.

Figure 2. Mass Breakdown of the SEP \& HPM spacecraft. Vehicle IMLEO $=\mathbf{5 9 , 8 0 0} \mathbf{~ k g}$.
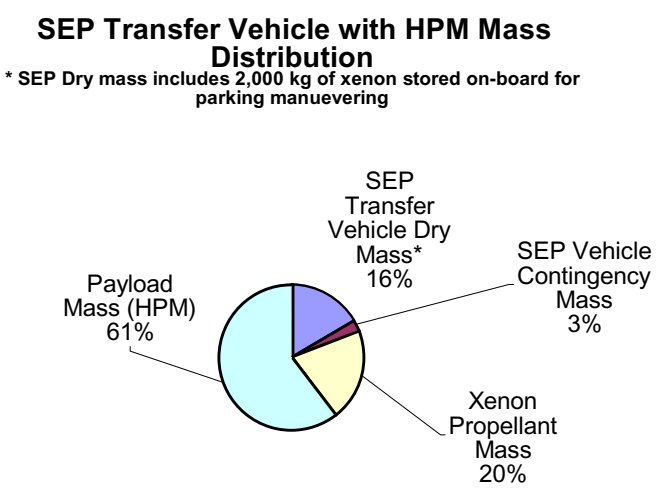

Figure 3. Mass Breakdown of the SEP Transfer Vehicle 'Dry' Mass. This mass includes $2000 \mathrm{~kg}$ of xenon stored on base pallet for parking maneuvers only. 'Dry' Mass $=11,300 \mathrm{~kg}$.

\section{SEP Transfer Vehicle Mass Distribution}

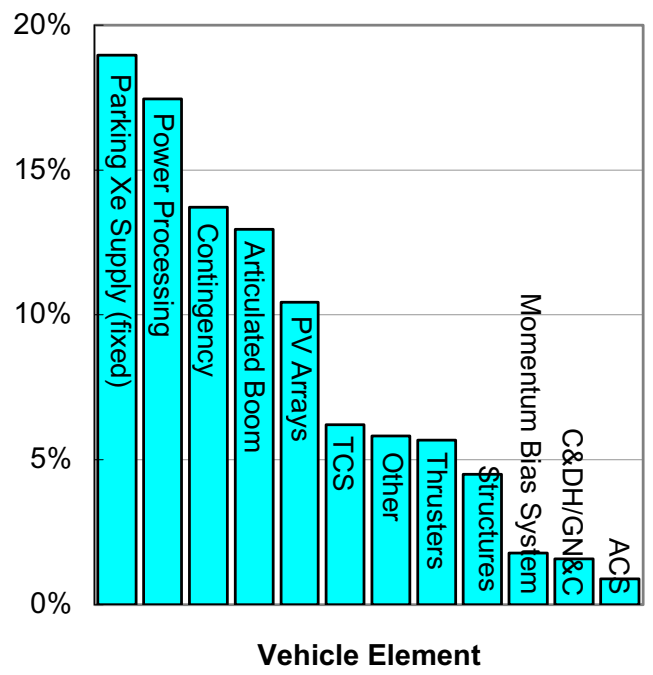

Figure 4. SEP Transfer Vehicle. PV arrays shown to scale. Thruster pallet at top of figure. HPM not included in figure.

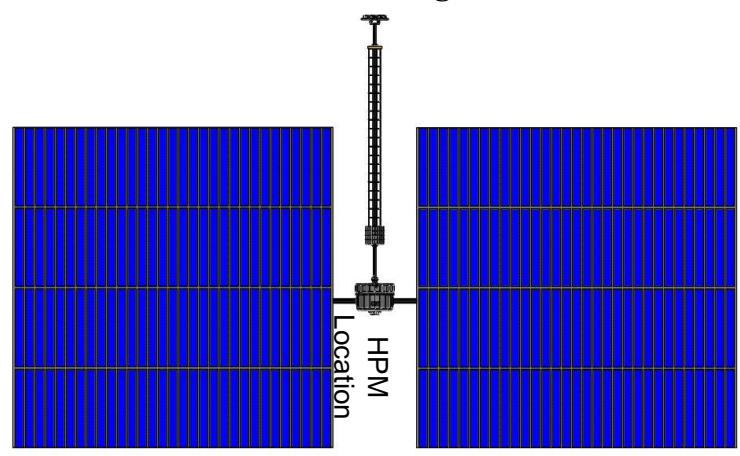

\section{OTHER MISSIONS}

In addition to the HPM mission for the RASC program, the SEP transfer vehicle system model has been successfully used in other recent studies. First, a study was undertaken by NASA Johnson Space Flight Center to 
look at the Lunar L1 Gateway mission architecture, with primary focus on the Gateway station and lunar missions. NASA GRC supported the definition of an SEP transfer vehicle to deliver 30 metric tons of propellant to LL1 within 180 days. Hall effect thrusters were employed in this mission because the shorter trip times mandated a higher thrust device. The important parameters of the SEP transfer vehicle developed for this mission are summarized in Table 7 . The propellant storage differed significantly between the Gateway Habitat mission and the HPM mission because in the former, all the xenon propellant resides at the base container, including return propellant for the SEP vehicle. A replaceable propellant container was added to the SEP transfer vehicle to facilitate propellant replenishment, which accommodated the change. For the RASC/ HPM mission, xenon propellant was stored on the HPM and piped into the SEP transfer vehicle during operation. The final vehicle design for the Gateway mission is illustrated in Figure 5.

Table 7. JSC Lunar Gateway Mission Requirements \& Results

\begin{tabular}{|c|c|}
\hline Requirement & Value \\
\hline Initial Mass in LEO & $66,800 \mathrm{~kg}$ \\
\hline $\begin{array}{l}\text { Delivered payload (not SEP, } \\
\text { xenon), }\end{array}$ & $30,000 \mathrm{~kg}$ \\
\hline Initial Altitude/ Inclination & $\begin{array}{c}400 \mathrm{~km} / \\
28.6^{\circ}\end{array}$ \\
\hline Final Altitude/ Inclination & $\begin{array}{c}320,000 \mathrm{~km} / \\
19.5^{\circ} \\
\end{array}$ \\
\hline Thruster type, \# of thrusters & $\begin{array}{l}12-50 \mathrm{~kW} \\
\text { Hall Thrusters } \\
(2,500 \mathrm{sec} .)\end{array}$ \\
\hline Power Generated & $584 \mathrm{~kW}$ \\
\hline Array area & $7,300 \mathrm{~m}^{2}$ \\
\hline $\begin{array}{l}\text { Xenon Propellant Load, Total } \\
\text { (Inbound) }\end{array}$ & $\begin{array}{l}21,500 \mathrm{~kg} \\
(4950 \mathrm{~kg})\end{array}$ \\
\hline Outbound Trip Time, days & 168 \\
\hline Mission Timeframe & 2011 \\
\hline
\end{tabular}

As part of the 2002 activities, the RASC program initiated a study into the possibility of utilizing power beaming from a large power station located at LL1. This central power station, which is also being analyzed at NASA GRC, is currently being sized to provide electrical power via laser beams for up to four vehicles simultaneously. This estimate was based on the traffic model for HPM fuel vehicles that supports activities
Figure 5. Lunar Gateway SEP Transfer Vehicle. PV arrays shown to scale; Hall thruster pallet shown at the bottom of the illustration, and the payload mass is the approximately square element shown attached to the base pallet near the center of the image.

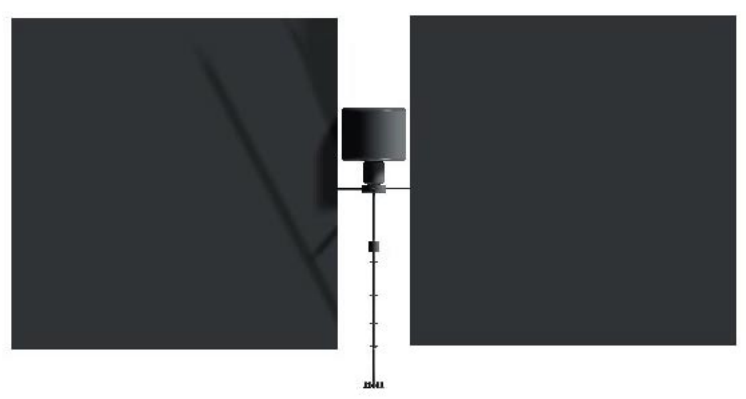

based at LL1. At this time, power generation technologies are being investigated-Nuclear fission versus photovoltaic, along with orbit analysis of the HPM vehicles and the central power station. In addition, the electric propulsion transfer vehicle is being investigated to determine the performance of a vehicle configured to use beamed power.

Finally, a study has been initiated to examine and assess the structural requirements and dynamics of the articulated boom implemented in all of the studies described within this report. This study will determine the limits of feasible application of the conformable boom and any subsequent limitations this may impose on the SEP stage application.

\section{CONCLUDING REMARKS}

A conceptual SEP vehicle design has been developed for a 2016 mission to transfer of a fuel vehicle to an Earth-Moon L1 libration point. This vehicle is able to deliver the target payload mass of approximately 36 metric tons to the destination within 270 days. The transfer vehicle with the fuel module has an IMLEO of approximately 59.8 metric tons, of that approximately 12 metric tons is xenon propellant. The vehicle uses 8 gridded ion thrusters operating simultaneously powered by large $\left(\sim 2,700 \mathrm{~m}^{2}\right)$ thin-film arrays. The spacecraft system model has been extended successfully to similar applications and continues to be evolved for larger mission sets. Further studies to refine the SEP transfer vehicle system model are underway in 2002. 


\section{REFERENCES}

${ }^{1}$ Mankins, J.C., and Mazanek, D.D., "The Hybrid Propellant Module (HPM): A new concept for space transfer in the Earth's neighborhood and beyond," presented at the $52^{\text {nd }}$ International Astronautical Congress meeting, Paper IAF-01-V3.03, Toulouse, France, October 2001.

${ }^{2}$ Dudzinski, L.J., "Design of a Solar Electric Propulsion Transfer Vehicle for a Non-Nuclear Human Mars Exploration Architecture," Presented at the $26^{\text {th }}$ International Electric Propulsion Conference, Kitakyushu, Japan, October 1999.

${ }^{3}$ Murphy, D., and Spence, B., "An Ultra-lightweight Thin-Film Solar Array System for PowerSail," presentation at Space Power Workshop, April 5, 2001.

${ }^{4}$ MacDonald Dettwiler Space and Advanced Robotics, Itd. (MD Robotics), Canadarm description, http://www.mdrobotics.ca/canaframe.htm

${ }^{5}$ MacDonald Dettwiler Space and Advanced Robotics, Itd. (MD Robotics), Canadarm 2 description, http://www.mdrobotics.ca/aboframe.htm
${ }^{6}$ AEC-Able Corp. Datasheet, Feb. 2000. http://www.aec-able.com/srtm/srtm_spex.htm

${ }^{7}$ Edelbaum, T.N., Sackett, L.L., and Malchow, H.L., "Optimal Low Thrust Geocentric Transfer," AIAA Paper 73-1074, Lake Tahoe, NV, October 1973.

${ }^{8}$ Kaufman, H.R., and Robinson, R.S., "Electric Thruster Performance for Orbit Raising and Maneuvering," J. Spacecraft and Rockets, 1984, 21, No. 2.

${ }^{9}$ Multiple reports, Progress in Astronautics and Aeronautics: Orbit-Raising and Maneuvering Propulsion: Research Status and Needs, Caveny, L.H., Ed.; AIAA: New York, NY, 1984, 89.

${ }^{10}$ Edelbaum, T.N., "Propulsion Requirements for Controllable Satellites," American Rocket Society Journal, August 1961, pp. 1079-1089.

${ }^{11}$ Stuhlinger, E., Ion Propulsion for Space Flight, (C 1964: McGraw-Hill, New York), pp. 77. 
Table 2. Required technology advancements projected to 2016 for SEP transfer vehicle development

\begin{tabular}{|c|c|c|c|c|}
\hline Technology & \multicolumn{3}{|c|}{ Figures of Merit } & Comments \\
\hline Power Generation & $\begin{array}{c}\text { Array } \\
\text { Specific } \\
\text { Power, } \\
\text { W/kg }\end{array}$ & $\begin{array}{c}\text { Efficiency, } \\
\%\end{array}$ & & \\
\hline Thin Film Photovoltaic & 400 & 20 & & \\
\hline Advanced Array Designs & 300 & $>40$ & & \\
\hline Quantum Dots & $>500$ & 60 & & $\begin{array}{l}\text { High risk/ high po- } \\
\text { tential technology }\end{array}$ \\
\hline Energy Storage & $\begin{array}{c}\text { Specific } \\
\text { Energy, } \\
\text { Wh/kg }\end{array}$ & Lifetime & $\begin{array}{c}\text { Depth of } \\
\text { Discharge, } \\
\%\end{array}$ & \\
\hline Full polymer batteries & 300 & $\begin{array}{l}20 \mathrm{yrs} \\
(\mathrm{GEO})\end{array}$ & 70 & $\begin{array}{l}\text { Does not include } \\
\text { power electronics } \\
\text { mass }\end{array}$ \\
\hline Future Flywheel & 150 & $>95$ kCyc. & 90 & $\begin{array}{l}\text { Includes power elec- } \\
\text { tronics mass }\end{array}$ \\
\hline $\begin{array}{l}\text { Passive Unitized Regenerative Fuel } \\
\text { Cell }\end{array}$ & $>1000$ & $\begin{array}{c}80 \% \\
\text { efficiency }\end{array}$ & - & $\begin{array}{l}\text { Specific energy is } \\
\text { function of discharge } \\
\text { time }\end{array}$ \\
\hline Power Processing & $\begin{array}{l}\text { Specific } \\
\text { Power, } \\
\text { kW/kg }\end{array}$ & $\begin{array}{c}\text { Efficiency, } \\
\%\end{array}$ & $\begin{array}{l}\text { Operating } \\
\text { Tempera- } \\
\text { ture, }{ }^{\circ} \mathrm{C}\end{array}$ & \\
\hline High Temperature PMAD system & 3.0 & 95 & 350 & \\
\hline 1200 V Power Distribution & 1.4 & - & - & \\
\hline Electric Propulsion & $\begin{array}{c}\text { Thruster } \\
\text { Specific } \\
\text { Mass, } \\
\text { kg/kWe }\end{array}$ & $\begin{array}{l}\text { Lifetime, } \\
\text { hours }\end{array}$ & & \\
\hline $50 \mathrm{~kW}$ Gridded Ion Thruster & 1.25 & 15,000 & & Xenon propellant \\
\hline $50 \mathrm{~kW}$ Hall Effect Thruster & 1.2 & 10,000 & & Xenon propellant \\
\hline 1.0 MW MPD Thruster & 0.3 & 8,000 & & Lithium propellant \\
\hline
\end{tabular}




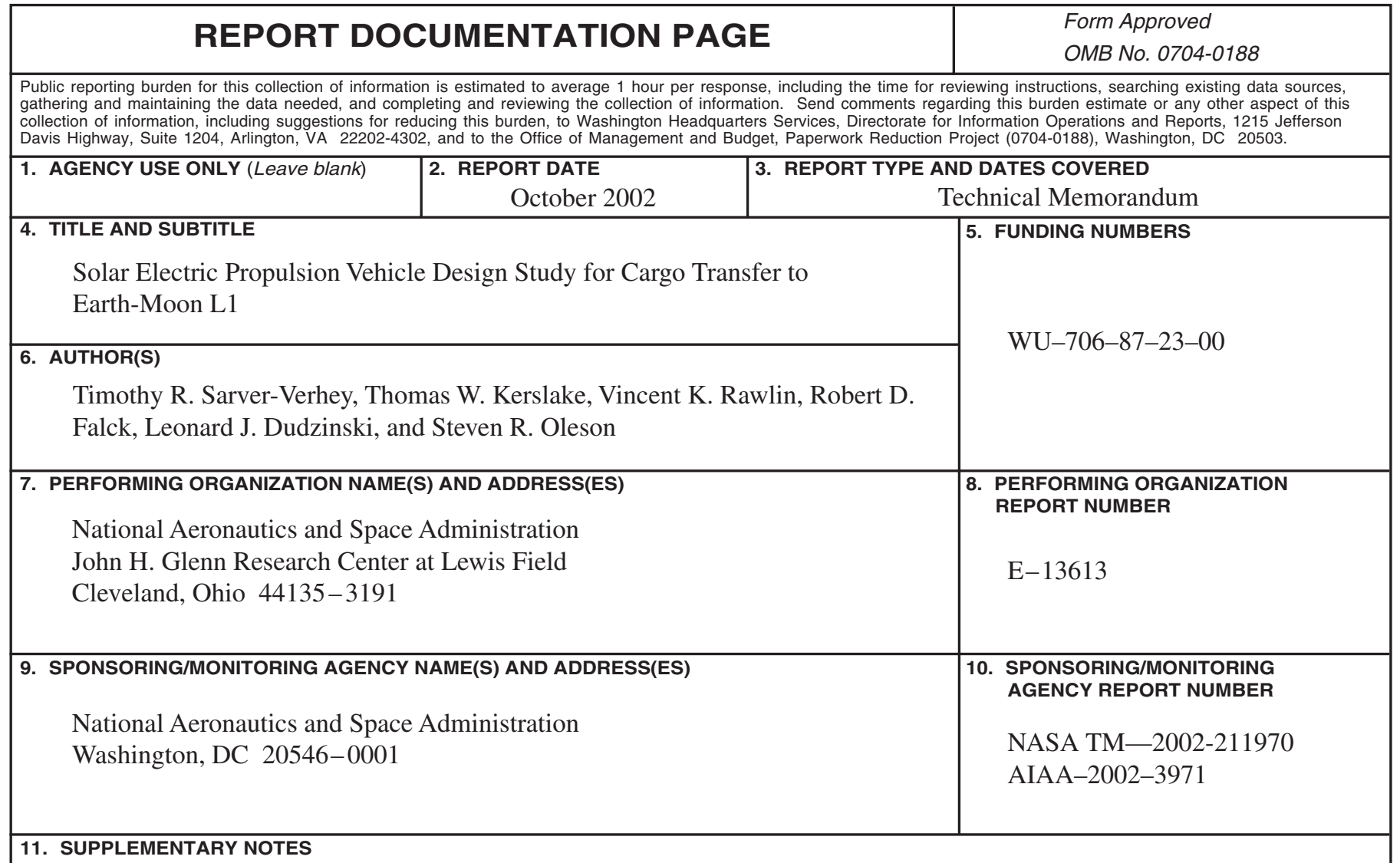

Prepared for the 38th Joint Propulsion Conference and Exhibit cosponsored by the AIAA, ASME, SAE, and ASEE, Indianapolis, Indiana, July 7-10, 2002. Responsible person, Timothy R. Sarver-Verhey, organization code 6920, 216-977-7458.

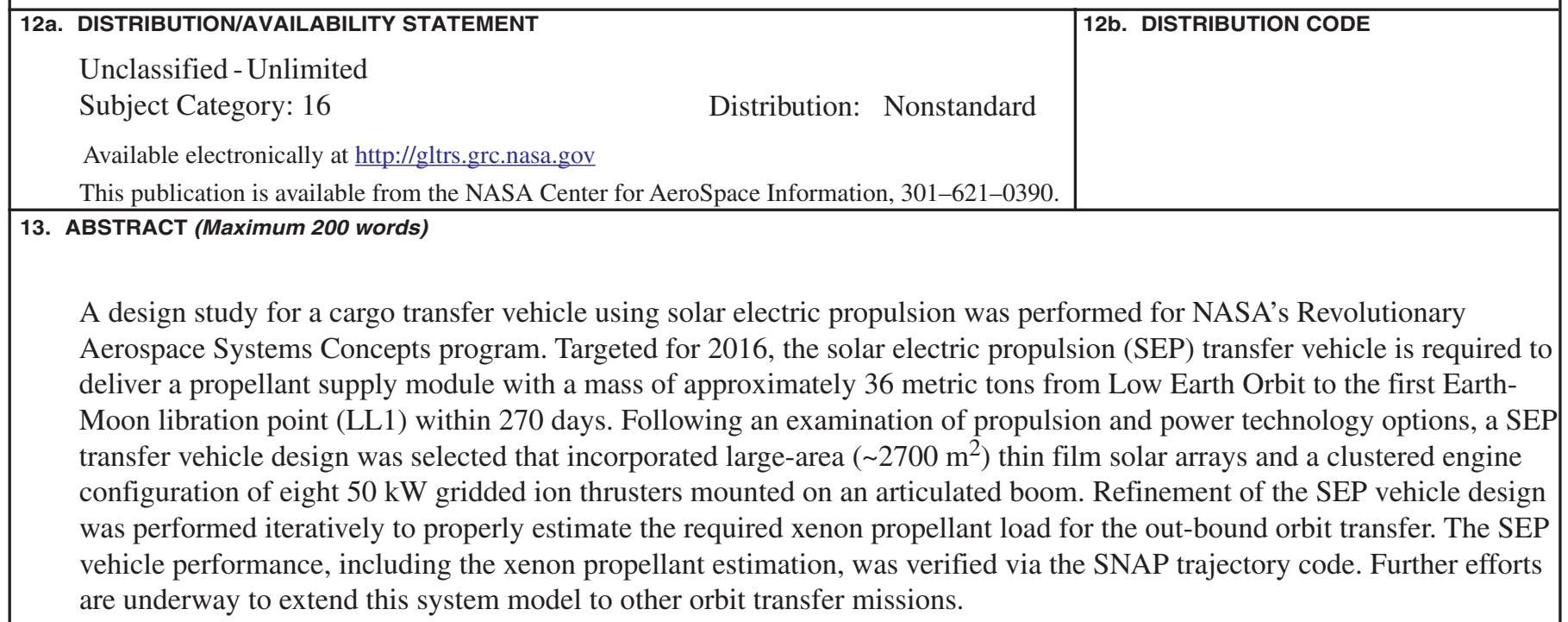

\begin{tabular}{|c|c|c|c|}
\hline \multirow{3}{*}{\multicolumn{3}{|c|}{$\begin{array}{l}\text { 14. SUBJECT TERMS } \\
\text { Electric propulsion; Ion thruster; Orbit transfer; Low thrust; L1; Hybrid propulsion } \\
\text { module; Solar electric propulsion; SEP; LEO }\end{array}$}} & \multirow{3}{*}{$\begin{array}{l}\text { 15. NUMBER OF PAGES } \\
15 \\
\text { 16. PRICE CODE }\end{array}$} \\
\hline & & & \\
\hline & & & \\
\hline $\begin{array}{l}\text { 17. SECURITY CLASSIFICATION } \\
\text { OF REPORT }\end{array}$ & $\begin{array}{l}\text { 18. SECURITY CLASSIFICATION } \\
\text { OF THIS PAGE }\end{array}$ & $\begin{array}{l}\text { 19. SECURITY CLASSIFICATION } \\
\text { OF ABSTRACT }\end{array}$ & 20. LIMITATION OF ABSTRACT \\
\hline Unclassified & Unclassified & Unclassified & \\
\hline SN 7540-01-280-5500 & & & $\begin{array}{l}\text { ndard Form } 298 \text { (Rev. 2-89) } \\
\text { scribed by ANSI Std. Z39-18 } \\
-102\end{array}$ \\
\hline
\end{tabular}

